\title{
THE EFFECT OF ROOM MATERIAL TO OVERCOME THE NOISE DUE TO MOTORCYCLE WORKSHOP ACTIVITY AT HOME BASED-ENTERPRISED NEARBY ROADWAY
}

\author{
Petty Debriana Austin*, Ima Defiana**, Dhany Arifianto*** \\ *) Master Student of Environmental Architecture, Department of Architecture, Fac- \\ ulty of Civil Engineering and Planning, Institut Teknologi Sepuluh Nopember, In- \\ donesia \\ **) Lecturer, Department of Architecture, Faculty of Civil Engineering and Plan- \\ ning, Institut Teknologi Sepuluh Nopember, Indonesia \\ ***) Lecturer, Department of Physics Engineering, Faculty of Industrial Technolo- \\ gy, Institut Teknologi Sepuluh Nopember, Indonesia \\ e-mail: petty7592@yahoo.com
}

\begin{abstract}
Home based-enterprised is currently booming in Indonesia. Home basedenterprised is a right choice for people who want to have a business that integrates with their home. From some of business which has the highest noise level is a home with motorcycle repair business. Because the source of noise in the workshop is the engine and other supporting machinery. Home business is generally situated near from roadway and has acoustic problems aspect. Motorcycle repair service located near from roadway receives noise from inside and from outside (roadway).

The sound sources distribute noise through building elements, such as walls, floors and ceilings. Thus it needs to be researched the elements of room that potentially reducing noise, especially noise that transmits through the airborne.

To determine the noise level and effect that transmit through the airborne, the study using physical data collection with field studies. While the method using the experimental methods with simulation methods where in its implementation procedures use some software like Ms. Excel and Ecotect to analyze the Sound Pressure Level (SPL) and Transmission Loss.

The result showed that the characteristic of the materials (Transmission Loss \& Leq) influence on noise through the airborne. Thus it is obtained the right solution to overcome and reduce the noise at shophouse through the selection of appropriate material that can reduce airborne noise. The appropriate organic and anorganic material selection are expected to be the solution of the existing problems. The experiment results show that all of the material (organic \& anorganic) can reach the goal, but the best result is combination of both material, the organic material and anorganic material.
\end{abstract}

Keywords: airborne, material, motorcycle workshop, shophouse, noise, transmision loss 


\section{INTRODUCTION}

Nowadays, home-based business is popular with the residences serve as a place of business services, office, and commerce. The developing of home business can not be separated by the public opinions that see a house is not only as a place to live, but also a workplace. The facilities and infrastructures as well as home locality should became essential elements that must be observed. So, the work activities at home are more productively while ensuring a good shelter where the paradigm of living and working applies by itself (Silas, 1993). The business types of home business such as office, salon, bakery, café, motorcycle workshop, printing and etc. From the various business types, home with motorcycle repair business near from the roadway has a big noise problem. It can be found easily in big cities. This is in accordance with the increasing of motorcycle users every year and the need of motorcycle repair services are quite high. In addition the condition of roadways where motorcyles pass through them each day, it will cause noise to the surrounding environment.

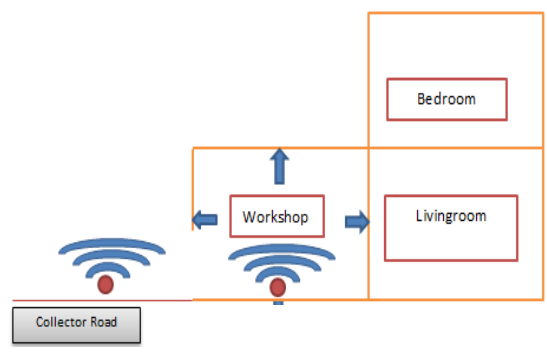

Figure 1. Spreading Noise from the Source of Noise

The noise problems in motorcyle wokshop of home based-enterprised above can be solved by determining the main source of noise in the workshop and noisy environments. Then, it can be known by the design application which can reduce the noise, either the distribution through the airborne or structureborne. These noise sources will spread out its noise either through the structure (interior elements such as walls, floors and ceilings) or through the air.

From the architectural aspect, space-forming elements (floors, walls, ceilings) in motorcyle repair business are the first elements which receive a sound from the sound source in the workshop. These three elements have a potential as barrier elements, absorptive elements or may be reflective sound elements. These are influenced by the characteristics of each material affected on the noise. So the results of comparison can be seen from the most influential elements in spreading out the noise into living space.

The selection of material for space elements to be tested has been set, namely organic and anorganic material. The reasons for selecting an organic material is the organic material capable of fulfilling its duties as an acoustic material and has been proven through conducted studies before, the selected organic materials are abundant in Indonesia and have not been used optimally, acoustic coating materials 
commonly available in the market are economically quite expensive. If the acoustic material component only can be replaced by organic material, the demand for acoustic coatings can be met with lower prices. While anorganic material with some reasons as material manufacturer in various shapes and appearances and easy in maintenance.

Based on the above explanation, the purpose of this study is to analyze the condition of the noise in motorcycle workshop home business located near from the roadway. Noise is produced by the noise source spreading out into homes through media or element, especially home building elements such as walls, floors and ceilings. Which room material is appropriate to be applied to the motorcycle workshop in order to create acoustic comfort inside. Besides that, knowing the characteristic influences at each material to overcome noise caused by the motorcycle wokshop home-based business, namely the noise causesd by activities of the workshops and roadway.

\section{THEORY AND RESEARCH METHODS}

\section{Noise}

The problems in the sound control involve three things: the sound source, receiver, and pathways between them depending on the medium. The mediums can be a gas, roof, walls, windows, or air. The sound source comes from outside or inside the building and the occurred problem is always related to the frequency.

Good background of noise level will provide an ideal environment depending on the space usage. These NC numbers show the background noise level between desirable minimum value and allowed maximum value. The dimension of background noise levels have been assigned according with the functions and activities that take place inside.

Table 1. Background Noise Level. Recommended Noise Criteria

\begin{tabular}{ccc}
\hline No & Room Type & NC Number \\
\hline 1 & Home & $25-35$ \\
2 & Hotel & $25-35$ \\
3 & Semi Private Office Private & $30-35$ \\
4 & Business office & $35-45$ \\
5 & Restaurant & $35-50$ \\
\hline \multicolumn{3}{c}{}
\end{tabular}

According to Mediastika, types of noise propagation can be distinguished by the mediums of sound waves:

1. Airborne Sound is the sound waves propagation through the air medium. This propagation type will go into building, If there are holes, slits, or cracks in building elements, especially on vertical element (wall). 


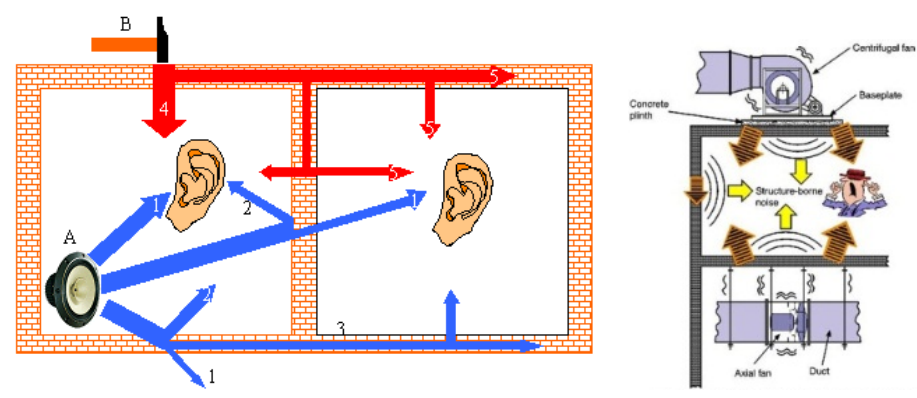

Figure 2. Airborne Sound and Structure Borne Ilustration Source: Internet, 2015

The workings of the barrier can be a reflection of sound waves back toward the source or in the other direction beneath the barrier or use objects of capable material of absorbing sound waves. The barrier objects are made from a material that is soft enough, the surface is not slippery, but have a sufficient thickness and weight will be able to work well (Mediastika, 2005).

2. Structureborne sound is a term used for the process the sound propagation through solid objects. In this context, a solid object associated with elements of the building itself, so it is called Structureborne sound. Propagation through building elements commonly occurs when the noise sources are bound or very close to those elements, for example bonding to or very close to the wall. (Mediastika, 2005).

room:

Some of methods that can be applied to prevent external noise into the

1. Solid Wall

A wall with one brick thickness is basically able to reduce incoming sound up to approximately $45 \mathrm{~dB}(\mathrm{~A})$. Each additional thickness of one brick is able to reduce the incoming sound up to $5 \mathrm{~dB}(\mathrm{~A})$. So the wall thickness of two bricks is equivalent with reduction up to $50 \mathrm{~dB}(\mathrm{~A})(45 \mathrm{~dB}(\mathrm{~A})+5 \mathrm{~dB}(\mathrm{~A})=50 \mathrm{~dB}(\mathrm{~A}))$. Cavity created between the wall will also provide extra reduction.

2. Window Glass Layer

Basically the layer of window glass which already duplicated two layers are still considered less in terms of acoustics as an "air gap". For better insulation, it is recommended that sheet of glass needs to be separated approximately $200 \mathrm{~mm}$ although the ideal distance of $60-80 \mathrm{~mm}$ is enough. Overall, the layer of glass whose an air gap is much better than window whose a single layer of glass with no air gap at all.

3. Sealing All Air Gap

This is very important because sound waves can pass through the gap, no matter how small it is. A place where needed an acoustic handling, the doors should or have a function as a refrigerator door which is sealed. So the cold air does not leak or the outside air does not come into. 
Acoustic insulation is an important factor in the comfort of a room. The Noise Criteria (NC) of building type and room type that is reviewed must be considered by an acoustic insulation. This is very influential because the building and the room have a different function. With the proper use of noise criteria, the a good sound insulation and comfort in the room can be maintained.

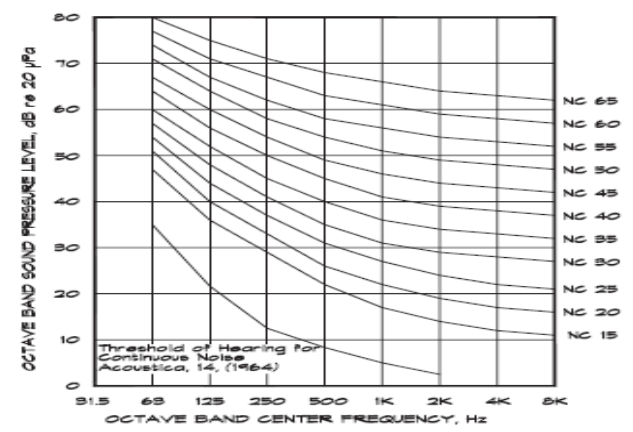

Figure 3. Noise Criteria Curve Source: Long, 2006

\begin{tabular}{|llc|}
\hline \multicolumn{1}{c}{ Type of Area } & Recommended NC or RC Criteria Range \\
1 & Private Residences & 25 to 30 \\
2 & Apartments & 25 to 30 \\
3 & Hotels/motels & \\
& a Individual rooms or suites & 30 to 35 \\
& b Meeting/banquet rooms & 25 to 30 \\
& c Halls, corridors, lobbies & 35 to 40 \\
& d Service/support areas & 40 to 45 \\
4 & Offices & 25 to 30 \\
& a Executive & 25 to 30 \\
& b Conference room & 30 to 35 \\
& c Private & 35 to 40 \\
d Open plan areas & 40 to 45 \\
e Computer equipment rooms &
\end{tabular}

Figure 4. Noise Criteria According to Building Function Source: Long, 2006

In the acoustic insulation, the quality of insulation can be described by the transmission loss. Transmission loss is the amount of insulation value in a partition, where the greater the loss the greater the value of the ability of a material to insulate sound (Hemond, 1983). The values of transmission loss are measured with certain frequency, from low frequency to high frequency. These values can be obtained from the following equation (Barron, 2001).

$$
R=L_{S}-L_{R}+10 \log \frac{S_{w}}{R_{r}} \quad N R=L_{S}-L_{R} \quad R=N R+10 \log \frac{S}{A}
$$

$\mathrm{R} \quad$ : Transmission loss $(\mathrm{dB}(\mathrm{A}))$

$L_{S} \quad$ : Sound pressure level rata-rata ruang pertama, sumber bunyi (dB (A))

$L_{R}$ : Sound Pressure Level rata-rata ruang kedua, penerima bunyi (dB (A))

$S_{w}$ : Area permukaan transmisi $\left(\mathrm{m}^{2}\right)$ 
$R_{r}$ : Besaran absorpsi ruang penerima ( $\mathrm{m}^{2}$.sabins)

NR : Noise Reduction (dB (A))

\section{Home-Based Enterprised}

According to Johan Silas (1993) on the general concept of working and living are included as social and cultural dimensions. Some details of the house can be categorized in the types of occupancy as follows:

1. Home is the type of home as a place to stay without any other significant activities. In this type is usually for upper-middle income bracket.

2. Home business is the type of a portion of the home used for productive (business) or economic activity. Consequently, it raises the relationship between aspects of production and home care.

The existence of a productive home or home business shows the home functions for human life. As a product of human technology for facility tools and the goal of human life.

The comparison or proportion from the two types (home and home businesses) contain on the following criteria:

1. Mixed Type. Type in which the function of the residence is in the same location with workplace. The home function is still dominant and the resident is still as a primary function.

2. Shared Type. The residences are separated from workplace in the same building. Access to the workplace is sometimes emphasized and separated where people outside the home are also involved.

3. Separated Type. In this type, the workplace is dominant and take most of the rest of room. Sometimes the residence is placed on the back.

\section{Roads Class in Surabaya}

The Government has arranged some rules regarding the division of class roads that indirectly referable to limit the noise level at a particular road class.

Table 2. Class Roads in Indonesia by Their Function

\begin{tabular}{|c|c|c|}
\hline No & Road Class & Spesification \\
\hline 1 & Arterial Road & $\begin{array}{l}\text { Serving the public transport with long-distance travel, high speed, } \\
\text { and the entrance is limited efficiently. }\end{array}$ \\
\hline 2 & $\begin{array}{l}\text { Collector } \\
\text { Road }\end{array}$ & $\begin{array}{l}\text { Serving shuttles collector with medium distance travel character- } \\
\text { istics, low speed, and the number of the entrance is limited. }\end{array}$ \\
\hline 3 & Local Road & $\begin{array}{l}\text { Serving public transport with close travel characteristics, low } \\
\text { speed, and the number of the entrance is not limited. }\end{array}$ \\
\hline
\end{tabular}


Table 3. Road Classes by PP no.43/1993

\begin{tabular}{|c|c|c|}
\hline No & Road Class & Specifications of Road and Vehicle \\
\hline 1 & $\mathrm{I}$ & $\begin{array}{l}\text { Arterial roads are passable by motor vehicles including cargo with a } \\
\text { maximum width of } 2.5 \mathrm{~m} \text {, a maximum length of } 18 \mathrm{~m} \text { and with the } \\
\text { axis of the heaviest loads of }>10 \text { tonnes. }\end{array}$ \\
\hline 2 & II & $\begin{array}{l}\text { Arterial roads are passable by motor vehicles including cargo with a } \\
\text { maximum width of } 2.5 \mathrm{~m} \text {, a maximum length of } 18 \mathrm{~m} \text { and with the } \\
\text { axis of the heaviest loads up to } 10 \text { tons.. }\end{array}$ \\
\hline 3 & IIIA & $\begin{array}{l}\text { Arterial or collector roads are passable by motor vehicles including } \\
\text { cargo with a maximum width of } 2.5 \mathrm{~m} \text {, length max. } 18 \mathrm{~m} \text { and the } \\
\text { heaviest maximum load axis } 8 \text { tonnes. }\end{array}$ \\
\hline 4 & IIIB & $\begin{array}{l}\text { Collector roads are passable by motor vehicles including cargo with } \\
\text { a maximum width of } 2,5 \mathrm{~m} \text { maximum length of } 12 \mathrm{~m} \text { and a heaviest } \\
\text { maximum load axis } 8 \text { tons. }\end{array}$ \\
\hline 5. & IIIC & $\begin{array}{l}\text { Local roads are passable by motor vehicles including cargo with a } \\
\text { maximum width of } 2.1 \mathrm{~m} \text { maximum length of } 9 \mathrm{~m} \text { and a heaviest } \\
\text { maximum load axis } 8 \text { tons. }\end{array}$ \\
\hline
\end{tabular}
Source: PP no.43/1993

As stated in www.surabaya.go.id that Arif Rahman Hakim road is included in the Type II - Secondary Collector. Following the designation of the road:

Table 4. Vehicle Speed according to the Types and Classes of Road

\begin{tabular}{clccc}
\hline & \multirow{2}{*}{ Street Location } & \multicolumn{3}{c}{ Index Designation } \\
\cline { 3 - 5 } & Primary \& Secondary Arterial Road & $\begin{array}{c}\text { Social fa- } \\
\text { cility }\end{array}$ & Housing & $\begin{array}{c}\text { Non } \\
\text { Housing }\end{array}$ \\
\hline Type I & 0,40 & 0,75 & 1,5 \\
Type II & Primary \& Secondary Collector Road & 0,30 & 0,60 & 1,2 \\
Type III & Local Road,width road $>=6 \mathrm{~m}$ & 0,15 & 0,25 & 0,5 \\
Type IV & Local Road, width road $<6 \mathrm{~m}$ & 0,05 & 0,10 & 0,20 \\
\hline \multicolumn{2}{c}{ Source: Direktorat Jenderal Bina Marga, Standar Perencanaan Geometrik Jalan Perkotaan, 1988 }
\end{tabular}

Table 5. Vehicle Speed according to the Types and Classes of Road

\begin{tabular}{ccc}
\hline Road type & Road Class & Speed $\mathbf{( k m} / \mathbf{h r})$ \\
\hline Type I & I & 100 atau 80 \\
& II & 100 atau 60 \\
Type II & I & 60 \\
& II & 60 atau 50 \\
& III & 40 atau 30 \\
IV & 30 atau 20 \\
\hline Source: Direktorat Jenderal Bina Marga, Standar Perencanaan Geometrik Jalan Perkotaan, 1988
\end{tabular}

From several the tables above, there are several things that may be associated with noise. The faster the velocity of vehicles, the higher the noise level in the vehicles. The higher the ratio of two-wheeled engine vehicle two stroke compared to a two-wheeled four stroke on a road section, then the higher the noise. 


\section{Sampling Method}

In this study is to find the subject of research and model determination using a purposive sampling method. Sampling aims to conduct by taking a subject which is not based on strata, random or region but a particular purpose.

The subject of research for sampling area or region needs a population data of Surabaya. The population data were selected based on population density. This is related to the level of noise that occurs in the environment. As state in www.smart.surabaya.go.id year 2011, The number of population in Surabaya reach $3,022,461$ inhabitants. Region of East Surabaya is the most populous region. Tabel 6 shows the total population in 2011.

Tabel 6. Total population of Surabaya city in 2011

\begin{tabular}{|c|c|c|c|c|c|c|c|c|c|}
\hline No. & Daerah & Kecamatan & 2005 (jiwa) & 2006 (jiwa) & 2007 (jiwa) & 2008 (jiwa) & 2009 (jiwa) & 2010 (jiwa) & 2011 (jiwa) \\
\hline 10 & Surabaya Timur & Tambaksari & 151.365 & 152.827 & 154.608 & 151.883 & 153.067 & 204.805 & 235.457 \\
\hline 11 & Surabaya Timur & Gubeng & 105.967 & 108.771 & 112.803 & 127.069 & 130.609 & 128.127 & 151.413 \\
\hline 12 & Surabaya Timur & Rungkut & 114.867 & 115.998 & 117.613 & 114.231 & 114.354 & 121.084 & 102.208 \\
\hline 13 & Surabaya Timur & Tenggilis Mejoyo & 56.023 & 56.972 & 58.068 & 59.502 & 60.667 & 72.467 & 54.761 \\
\hline 14 & Surabaya Timur & Gunung Anyar & 88.927 & 90.311 & 91.866 & 93.706 & 94.199 & 62.121 & 50.761 \\
\hline 15 & Surabaya Timur & Sukolilo & 32.276 & 33.017 & 33.681 & 35.785 & 36.587 & 119.873 & 107.361 \\
\hline 16 & Surabaya Timur & Mulyorejo & 34.687 & 35.602 & 36.623 & 38.178 & 38.778 & 94.728 & 85.251 \\
\hline \multicolumn{8}{|c|}{ Source: smart.surabaya.go.id }
\end{tabular}

From the seven districts, East Surabaya (see Table 6) whose the busiest road area has been selected. On www.surabaya.go.id says that there are about 120 roadtype collector in Surabaya, followed by 77 arterial roads type. So from here, selected 7 districts in East Surabaya which have a collector road class. Where the characteristics of this collector roads class is the road that serve the transportation collection or the division, such as medium traveling distance, medium average speed, the width road of not less than $7 \mathrm{~m}$. So that, this roadways have potential to become a noise source due to daily traffic events.

The next stage is the selection of road sections collector which allocated 7 districts in east Surabaya as a commercial area. It can be seen on the Surabaya designation map, the collector road sections in East Surabaya. Here is an example of designation map of commercial area in East Surabaya, shown by pink area.

From some commercial areas with collector roads type in east Surabaya, selected some roads that are considered to have a heavy traffic. Besides that, it also has the same function of the building as a home with motorcycle repair business. The obtained data is presented in Table 6 . 


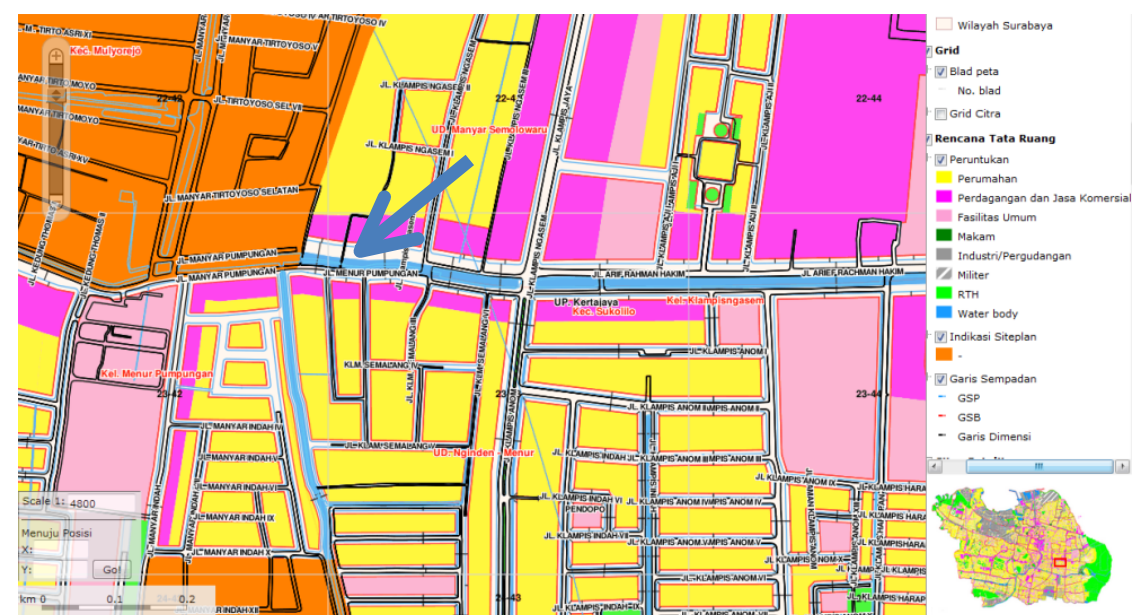

Figure 5. Designation Map of Surabaya Source: smart.surabaya.go.id

Tabel 7. Motorcycle Repair Home-Based Business Samples in East Surabaya

\begin{tabular}{cccc}
\hline & Motorcycle Workshop & Road Width & Width House \\
\hline Arif Rahman Hakim & Nogobaru Motor & $7 \mathrm{~m}$ & $6 \mathrm{~m}$ \\
Street & Indie Motor & $7 \mathrm{~m}$ & $5 \mathrm{~m}$ \\
& Nadia Motor & $7 \mathrm{~m}$ & $5 \mathrm{~m}$ \\
& Kania Motor & $7 \mathrm{~m}$ & $6 \mathrm{~m}$ \\
& Anugrah Motor & $7 \mathrm{~m}$ & $6 \mathrm{~m}$ \\
Menur Pumpungan & Aji Motor & $7 \mathrm{~m}$ & $4 \mathrm{~m}$ \\
Street & Bengkel Karunia & $7 \mathrm{~m}$ & $4 \mathrm{~m}$ \\
& AHASS Daya Motor & $7 \mathrm{~m}$ & $6 \mathrm{~m}$ \\
Nginden Semolo & Alfa Motor no.26 & $7 \mathrm{~m}$ & $4 \mathrm{~m}$ \\
Street & Makmur Jaya & $7 \mathrm{~m}$ & $5 \mathrm{~m}$ \\
& Aman jaya motor & $7 \mathrm{~m}$ & $6 \mathrm{~m}$ \\
& Sintoel Motor & $7 \mathrm{~m}$ & $6 \mathrm{~m}$ \\
Manyar Street & W \& W Motor & $7 \mathrm{~m}$ & $4 \mathrm{~m}$ \\
& Karunia Motor (bike point) & $8 \mathrm{~m}$ & $8 \mathrm{~m}$ \\
& Utama Motor & $8 \mathrm{~m}$ & $10 \mathrm{~m}$ \\
& Budi Jaya Motor & $8 \mathrm{~m}$ & $8 \mathrm{~m}$ \\
& Perkasa Motor & $8 \mathrm{~m}$ & $10 \mathrm{~m}$ \\
& Kiki Motor & $8 \mathrm{~m}$ & $10 \mathrm{~m}$ \\
\hline
\end{tabular}

Based on the sampling criterias that have been made, from several types of categories for home business with a motorcycle workshop, chosen one sample which represents business home with motorcyle repair service located in the dense settlements and near from the roadway. The sampling was focused in east Surabaya. With the existing building that has been determined, the next handling is on several parameters that affects the research variables. Standard parameters in this study using a Sound Pressure Level and Transmission Loss. 
After that, the related variables above are associated with the room materials which have been applied and analyzed. Analysis of this materials consist of comparing the acoustic quality of environmental-friendly materials and conventional materials.

\section{Subject Research and Model Determination}

The research subject is focused on home enterprised that located in the dense settlement and nearby the roadside (secondary collector roads), which has the acoustic comfort disruption of business activity due to motorcyle workshop and roadway. This study uses data sampling method with purposive sample to determine the type of building subject. The definition of purposive sample is a sampling technique that is not focused on broad generalizations population and more focused to determine useful criteria in a group or population (Groat and Wang, 2002). There are considerations of sampling data criteria from the sampling method as follows:

1. Located in east Surabaya.

2. The sideroad whose similar road class with the type of secondary collectors ( $\mathrm{J} 1$.

Manyar, Jl. Menur Pumpungan, J1. Arif Rahman Hakim, Jl. Nginden Semolo).

3. Activities are likely similar: motorcycle workshop.

The next stage is the survey some types of residential building area, home business or shophouse. This aims to determine research area samples. There are several width sample of business houses which are used as a reference for determining the applied broadness. Based on sampling (table 6), it can be seen broadness typology of motorcyle repair home business from $4 \mathrm{~m}-10 \mathrm{~m}$. Below are the survey results of home business in dense settlement areas, as follows:

Table 8. Size Categories of House Business Building in East Surabaya.

\begin{tabular}{cclc}
\hline No. & Land Building Area $\left(\mathbf{m}^{\mathbf{2}}\right)$ & Building Types & $\begin{array}{c}\text { Zoning home and work } \\
\text { space ratio }\end{array}$ \\
\hline 1. & $4.00 \mathrm{~m} \times 16.00$ & Shophouse & $2: 4$ \\
2. & $5.00 \mathrm{~m} \times 23.00$ & Shophouse & $2: 4$ \\
3. & $6.00 \mathrm{~m} \times 18.00$ & Home Business & $1: 4$ \\
4. & $8.00 \mathrm{~m} \times 20.00$ & Residence & $1: 4$ \\
5. & $10.00 \mathrm{~m} \times 18.00$ & Residence & $1: 4$ \\
\hline
\end{tabular}

From the comparison of volume and the ratio of residential zoning with business spaces, it can be concluded that most home businesses along the roadway have an area and building typologies such as the following: 


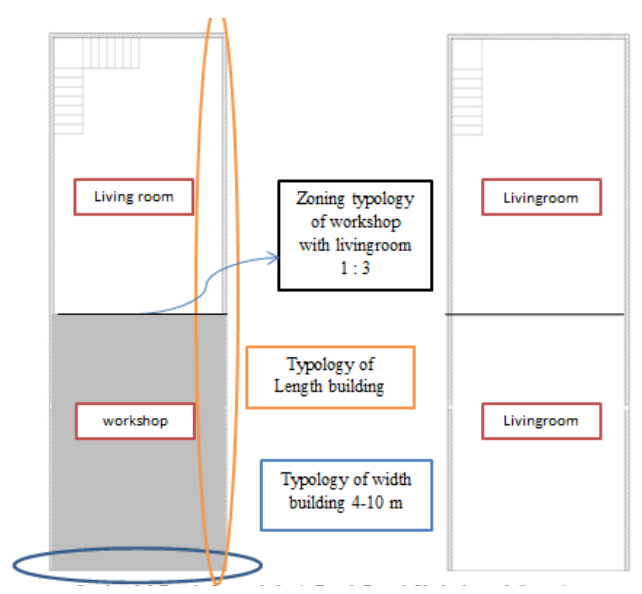

Figure 6. 1st Floor Plan (Left) and 2nd Floor Plan (Right)

Based on the above sampling, building research subjects will be taken to the typology in the range of 6-10 m wide area, length of $18-20 \mathrm{~m}$, and the ratio of business space zoning with residential space 1: 4 . It can be seen in Table 7, zoning 1: 4 is a home business zoning in general. From the analysis of selected building typology is home businesses no.3, size of the $6.00 \times 18.00$ with similar activities that can meet the criteria of study. This home business is also in densely populated settlements and is situated on the roadside with a secondary collector class.

\section{Data Collection}

The required datas for this study are determined based on the variable and the sample used. Data types are classified into two, namely:

1. The Primary Data. The obtained data from a researcher is used for preliminary data research. Here are the primary data in this study:

a. The samples data area of a few home business with motorcyle workshop in east Surabaya.

b. Data types of road class in Surabaya.

c. Data of zoning home business based on activity.

d. Data of Sound Pressure Level inside the room.

e. Data of Sound Pressure Level outside the room.

2. The Secondary Data. The secondary data are obtained from relevant sources and without direct measurement process. Here are some form of secondary data:

a. The data requirements of the noise acoustic parameters, Sound Pressure Level which will show the noise mapping at a motorcyle repair business.

b. Literature study material related to this study.

c. Acoustic studies of the Transmission Loss that can be correlated with existing needs 


\section{RESULTS AND DISCUSSION}

Research subject in this study was obtained from the sampling process. Research subjects must be determined and identified first to know what things are influential. The approachings of subject analysis are qualitative and quantitative data, which are expected to help find the right method.

The location of the research subject is on Jl. Arif Rahman Hakim, East Surabaya. The neighborhood of the research subject has several characteristics which located in dense settlements in the surrounding area where many found various types of home businesses both similar and dissimilar. With this type of secondary collector roads where the width of the road for this type is not less than $7 \mathrm{~m}$, the speed of the plan at least 20 (twenty) $\mathrm{km}$ per hour. Here is a site-plan of the research subject.

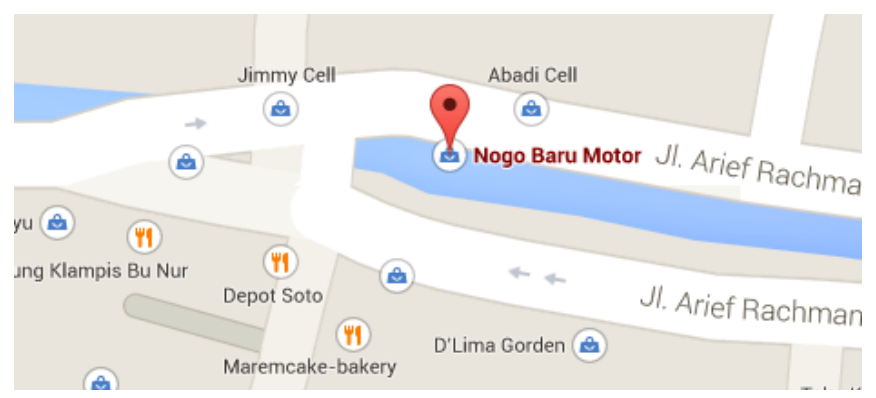

Figure 7. Site Plan of the Research Subject

Source: www.google.com/maps/place/Nogo+Baru+Motor

Field measurements are conducted in one day, on Thursday (March 5, 2015) which was considered to represent all day. Based on interviews with owner, the workshop is open every day starting at 8:00 AM to 5:00 PM. The motorcycle workshop that has a number of employees 6 people, every day is always full of visitors. So it can not distinguish between working days and holidays.

Field data collecting is an image of the existing condition of motorcyle repair home business site plan, furniture layout, furniture dimensions, room dimensions and material elements. The existing condition is shown in Figure 9.

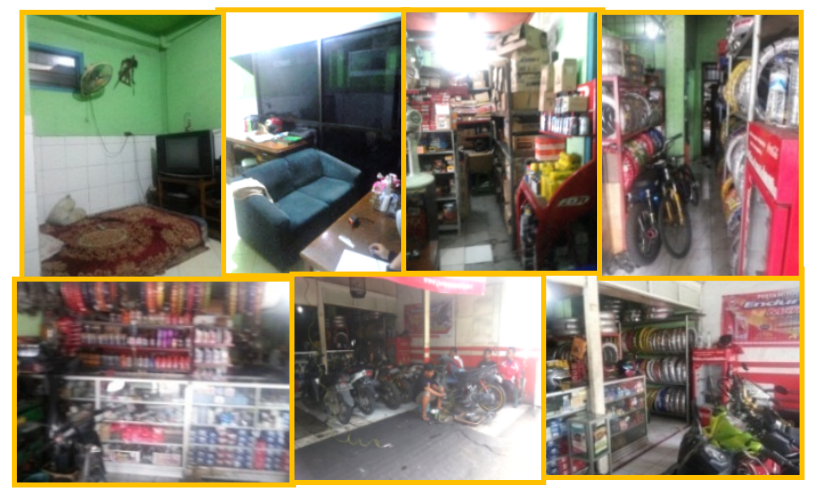

Figure 8. Existing Photos of the research subject 

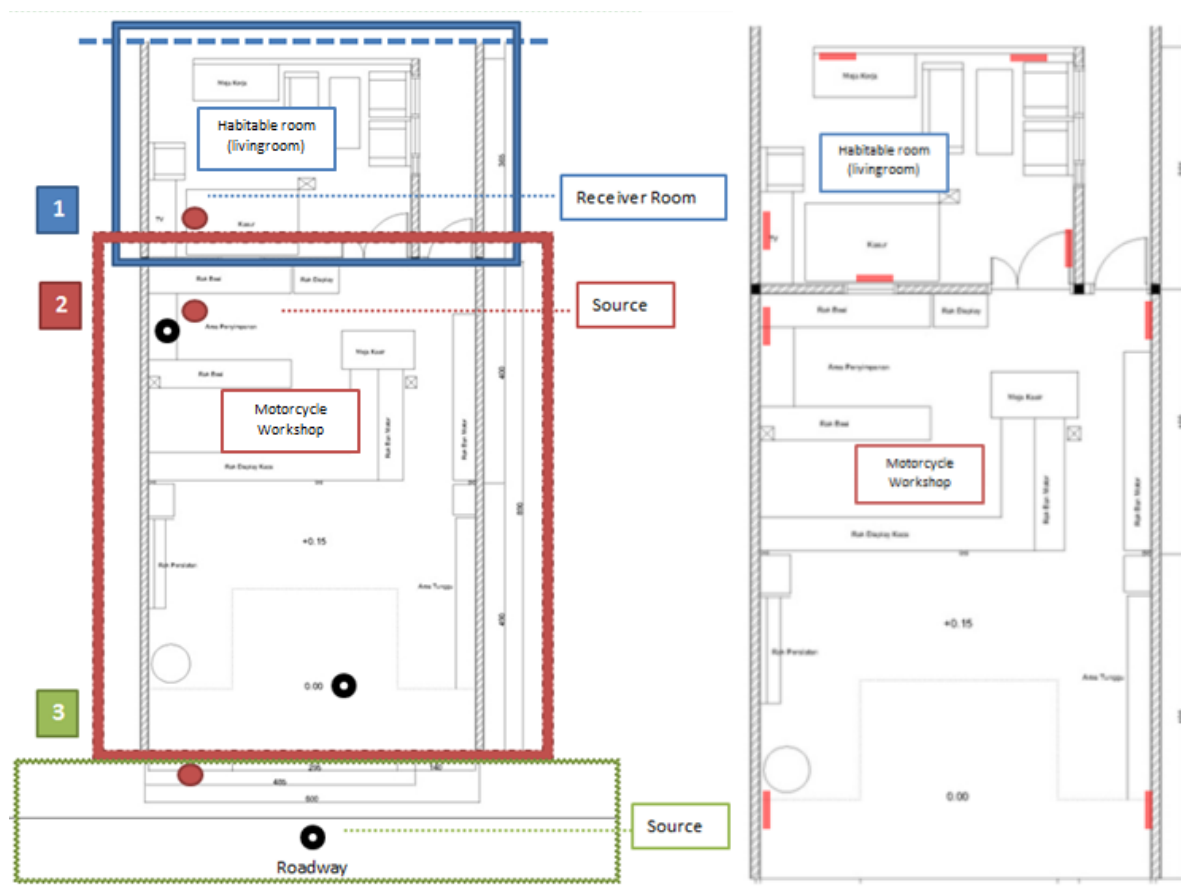

Figure 9. Airborne noise collecting point using SLM (left).

Taking the point of Structure borne collecting point noise using Vibrometer (right). Note :

- Black Point is a source of noise, where the workshop area is detected with two points, the location of compressor and the point in motor area.

- Red Point is the placement of SLM with current SPL data collection.

- Red rectangle is vibrometre.

To test the acoustic quality of habitable room on this research using data collection SPL both in room (workshop) and outside the habitable room (roadway). Although basically experiments are situated as an original existing building, on the application of the experimental layout and construction materials are still conditioned with the motorcyle repair home business. Here are the zoning and data retrieval reference point SPL using SLM \& Vibrometre and tripod connected to software on laptop.

Total of SLM placement are 3-points: roadway, motorcycle workshop and habitable room. On roadway (green zoning) laid 1 SLM on the edge of workshop with tripod's height of $120 \mathrm{~cm}$ and sensor direction towards the roadway to collect data roadway noise.

For zoning workshop is also in place 1 SLM, the SLM position is within 60 $\mathrm{cm}$ of the wall bordering the habitable room, $70 \mathrm{~cm}$ of the left wall of workshop and $20 \mathrm{~cm}$ from the compressor which is located in the left side workshop wall. The position of the front-facing sensor for measuring the noise generated by the workshop activities, from the compressor sound, engine noise and workshops activity. 

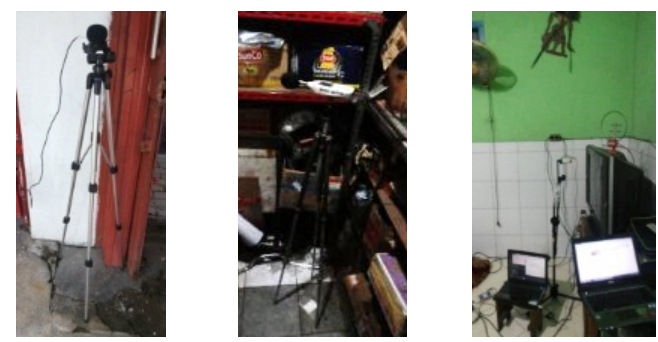

Figure 10. SLM Position in Roadway (left),

Garage and Habitable Room (living room)

The SPL data in the habitable room also taken by putting 1 SLM behind the garage wall. 3 SLMs are placed at the same height of $1.2 \mathrm{~m}$ from the floor and parallel to each other. Basically the direction is toward the SLM at the time of data collection depending on the direction of the analyzed receiver. Results of selected data will be directed to accurate data and covers all the design needs of habitable room.

SPL measurements was conducted 3 times an hour with an interval of 10 minutes simultaneously between 3 points. Then the SPL data were transferred to the laptop and begin processing the data using Microsoft Excel. SPL value is used to determine Transmission Loss which as one of the test data in this study.

The noise is measured through propagation of structureborne using Vibrometer, because SLM can not reach the low frequencies produced by structureborne. Here is a picture of vibrometer mounting points with total of 9 points. And they were checked three times with every half-hour time. Starting at 14:00 PM.

\section{The Results of Sound Pressure Level Data at The Research Subject}

Results of noise measurement through SLM were recorded using Ms. Excel. The data value of Sound Pressure Level (SPL) were obtained from each point, then averaged for each time point, so each time point of measurement is 1 Leq value. Then compared the results between the three measurement points. Following are the results of field measurement data graphs:

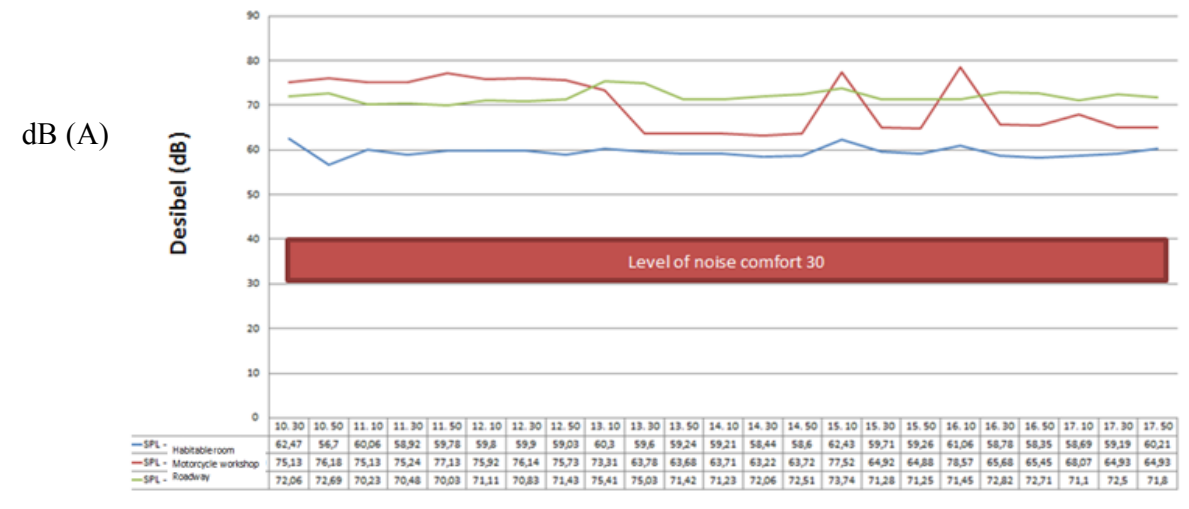

Figure 11. Leq of Research Subject 
Based on the results of existing Leq measurements, it's seen in the graph that the average $\mathrm{dB}(\mathrm{A})$ on habitable room is above the allowable noise limit exposure levels. The distance between the noise exposure level with the noise in the habitable room around $20 \mathrm{~dB}(\mathrm{~A})$. While the two sources of noise, the garage and roadway are far above standard noise level, ranges from $35 \mathrm{~dB}(\mathrm{~A})$. But with the current existing condition, the generated noise from the two sources at least able to reduce the noise that goes into habitable room, although it has not been able to reach the standard of allowable noise limit level.

From the graph it can be seen the noise condition of the research subject. The two sources of noise affects the acoustic comfort in the occupancy. In fact, the current condition has not able to fullfil the acoustic comfort of occupancy, because the ability of the dividing partition between the two spaces (workshops and occupancy) is currently only able to reduce the value of NR range of $10 \mathrm{~dB}(\mathrm{~A})$. While the good partition that can reduce external noise is between 25-30 dB (A), in order to achieve the standard noise level.

The results of structure-borne measurements (vibrometre) are taken $3 x$ every half an hour which starts at 14.00, it can be seen in Table 8, 9, 10 .

Table 9. The Results of Structure Borne $1(\mathrm{~mm} / \mathrm{s})$

\begin{tabular}{ccccccccc}
\hline 1 & 2 & 3 & 4 & 5 & 6 & 7 & 8 & 9 \\
0,1 & 0,1 & 0,1 & 0,1 & 0,1 & 0,0 & 0,0 & 0,0 & 0,0 \\
\hline
\end{tabular}

Table 10. The Results of Structure Borne $2(\mathrm{~mm} / \mathrm{s})$

\begin{tabular}{ccccccccc}
\hline 1 & 2 & 3 & 4 & 5 & 6 & 7 & 8 & 9 \\
0,1 & 0,1 & 0,1 & 0,1 & 0,1 & 0,0 & 0,0 & 0,0 & 0,0 \\
\hline
\end{tabular}

Table 11. The Results of Structure Borne $3(\mathrm{~mm} / \mathrm{s})$

\begin{tabular}{ccccccccc}
\hline 1 & 2 & 3 & 4 & 5 & 6 & 7 & 8 & 9 \\
0,1 & 0,1 & 0,1 & 0,1 & 0,1 & 0,0 & 0,0 & 0,0 & 0,0 \\
\hline
\end{tabular}

\section{Analysis}

Besides the research subject located on the edge of roadway, it is also affected noisy street and also gets noisy from inside the building itself (the garage). So it can be said in this study that there are two sources of noise from outside (road) and inside (workshop). 


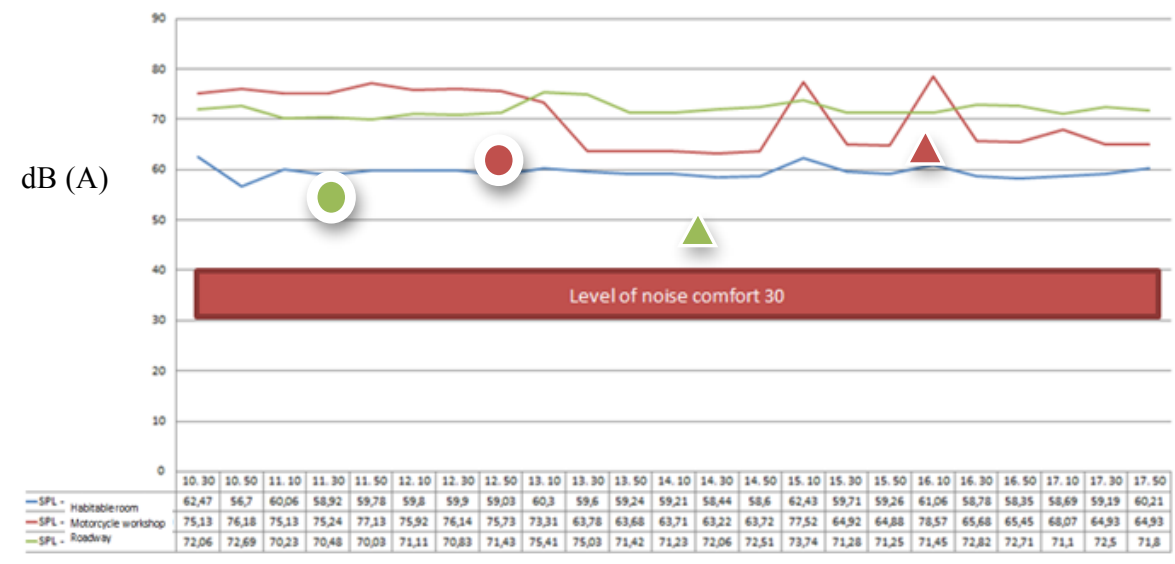

Figure 12. Noise Leq of Research Subject

Based on the chart above, the noise of roadway (green line) is one of the sources of noise that affects the acoustic comfort of occupancy where the highest point (red round) is at 13:10 which amounted to $75.41 \mathrm{~dB}$ (A). This could be due to many factors, such as the large volume of vehicles, vehicle horns, and the vehicle drove at high speed. And the lowest point (round green) is on at 11:50 amounting $70.03 \mathrm{~dB}(\mathrm{~A})$. The highest point (at 13:10) on the roadway shows $75.41 \mathrm{~dB}(\mathrm{~A})$, the receiving room (occupancy) shows the noise level of $60.3 \mathrm{~dB}(\mathrm{~A})$. This shows that the noisy road decreased by $15.11 \mathrm{~dB}(\mathrm{~A})$ into the occupancy.

Based on the graph, instability is on the low frequency but there is a significant increasing in noise starts at a frequency of $500 \mathrm{~Hz}$ to $2000 \mathrm{~Hz}$ with a range of about $51 \mathrm{~dB}(\mathrm{~A})$ noise $-56 \mathrm{~dB}(\mathrm{~A})$. So it can be presented in the table below, the frequency range and noise level produced by noise sources (roadway and workshop).

Table 12. Results of Two Sources Noise Range

\begin{tabular}{ccc}
\hline Noise Source & Frequency Range & Noise level Range (dB (A)) \\
\hline Roadway & $315 \mathrm{~Hz}-6300 \mathrm{~Hz}$ & $54 \mathrm{~dB}(\mathrm{~A})-62 \mathrm{~dB}(\mathrm{~A})$ \\
Motorcycle Workshop & $500 \mathrm{~Hz}-2000 \mathrm{~Hz}$ & $51 \mathrm{~dB}(\mathrm{~A})-56 \mathrm{~dB}(\mathrm{~A})$ \\
Reduced Frequency & & $500 \mathrm{~Hz}-2000 \mathrm{~Hz}$ \\
\hline
\end{tabular}

From both noise sources, the highest noise level is in the frequency range of $500 \mathrm{~Hz}$ to $2000 \mathrm{~Hz}$, so the range will be set to determine the materials which used at a later stage. Because the elected frequencies are included in the category of high frequency, the material which will be applied to experiments must reduce the noise at that frequency. 


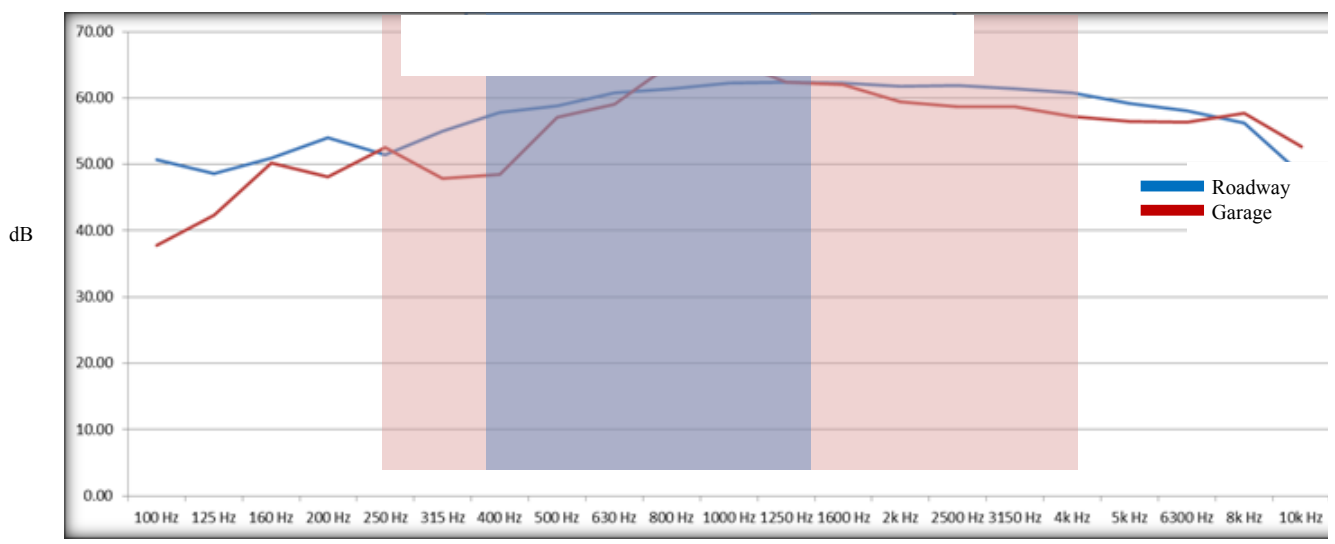

Figure 13. Graph of frequency slices which will be taken

\section{Organic \& Anorganic Materials}

The walls are vertical elements of the building or room that will deliver the sound waves directly. This is different from the floor and ceiling which are in horizontal position, so it does not deliver the noise directly. The research shows that the use of the principle of sound insulation in the walls would more effectively reduce the propagation of sound rather than the use of floor or double ceiling (Templeton and Saunders, 1987).

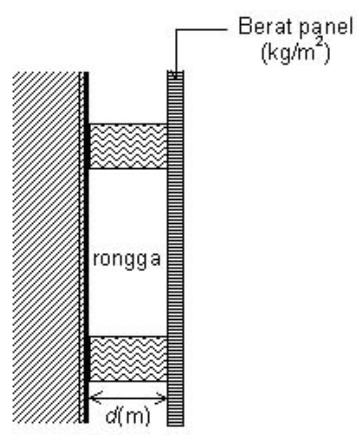

Figure 14. Example of

the application of

double wall with air cavity

The design in calculation refers to some of organic material that has been tested through the acoustic quality of some previous studies. As research conducted by Suranto about the acoustic panel of corncob waste and bagasse as well as the research from Kartika Ratri, regarding the coco fiber composites and phenol formaldehyde resin. Here is a summary of material characteristics which will be applied to the design of occupancy area at motorcyle repair home business(research subject). 
Table 13. Organic Material Characteristics

\begin{tabular}{clccc}
\hline No. & \multicolumn{1}{c}{ Material } & a & Thickness & Frequency \\
\hline 1. & Corncob Composite-PVAc & 0,63 & $15 \mathrm{~mm}$ & $0-1800 \mathrm{~Hz}$ \\
2. & $\begin{array}{l}\text { Coconut Coir Composite and } \\
\text { Phenol formaldehyde resin (5:3) }\end{array}$ & 0,984 & $1,5 \mathrm{~cm}$ & $756-6400 \mathrm{hz}$ \\
3. & Bagasse & 0,8 & $3.23 \mathrm{~cm}$ & $452-2000 \mathrm{~Hz}$ \\
\hline
\end{tabular}

Table 14. Anorganic Material Characteristics

\begin{tabular}{clcc}
\hline No. & \multicolumn{1}{c}{ Material } & a & Dimension/Thickness \\
\hline 1. & Wall (plester/cat) & 0,02 & $15 \mathrm{~cm}$ \\
2. & White tile & $0,01-0,02$ & $30 \times 30 \mathrm{~cm}$ \\
\hline
\end{tabular}

\section{Design Process}

To determine the material of design application which will be used in residential space, the existing of acoustic condition needs to be known with the design conditions that exist in the field. After having the magnitude of TL in the existing partitions, then the calculating of Transmission Loss value can be achieved through material design solutions. Here is the calculation of the condition's existing partitions with walls and a ceramic material as shown in following 3D.

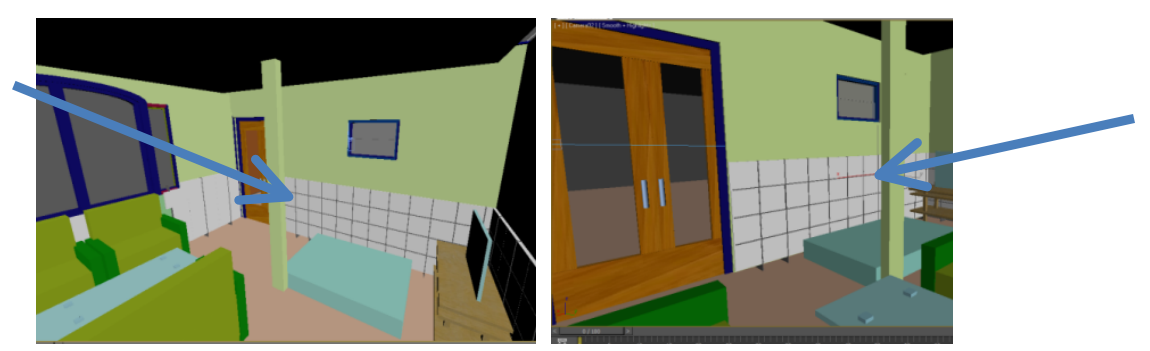

Figure 15. Wall Partition Material of Habitable Room and Garage

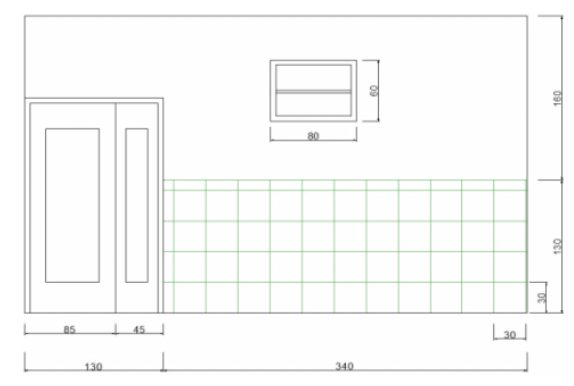

Figure 16. Figure of Habitable Room and Garage Wall Partition

The reduction values, the whole of partitions area $(\mathrm{S})$ and the value of $\mathrm{A}$ from the multiplication of material area (s) with the absorption coefficient $(\alpha)$ are 
needed to determine TL. Based on the image above(Figure 5.9) 13.63 S is derived from the length multiplied by the width of the field. As for the other calculations described as follows.

$$
T L=N R+10 \log \frac{S}{A}
$$

Here is the result of transmission loss of the existing partition field in the frequency band of 500-2000 Hz.

Table 15. TL (dB (A)) Calculating at frequency of $500-2000 \mathrm{~Hz}$

\begin{tabular}{cccccccc}
\hline Existing & $500 \mathrm{~Hz}$ & $630 \mathrm{~Hz}$ & $800 \mathrm{~Hz}$ & $1000 \mathrm{~Hz}$ & $1250 \mathrm{~Hz}$ & $1600 \mathrm{~Hz}$ & $2000 \mathrm{~Hz}$ \\
TL & 21.97 & 21.17 & 29.89 & 30.29 & 26.61 & 28.37 & 26.70 \\
\hline
\end{tabular}

Then the value of TL per frequency band is used to find LP2 which shows the value of each noise frequency in the room. Standart of comfort value in family room or home of LP2 is 30-35 dB (A).

Table 14 shows that in all frequency bands of LP2 value exceed $35 \mathrm{~dB}(\mathrm{~A})$, neither of the calculations manually or using SLM (data field). It shows that the design of the existing partition is still not able to reach a predetermined acoustic comfort.

It is necessary to design a further material processing in order to achieve an acoustic comfort in the desired occupancy area.

Table 16. LP2 (dB (A)) Calculating (Occupancy) at frequency of $500-2000 \mathrm{~Hz}$

\begin{tabular}{cccccccc}
\hline & $500 \mathrm{~Hz}$ & $630 \mathrm{~Hz}$ & $800 \mathrm{~Hz}$ & $1000 \mathrm{~Hz}$ & $1250 \mathrm{~Hz}$ & $1600 \mathrm{~Hz}$ & $2000 \mathrm{~Hz}$ \\
$\begin{array}{c}\text { LP2 (manual } \\
\text { calculation) }\end{array}$ & 47.97 & 50.52 & 47.98 & 48.32 & 48.62 & 46.48 & 45.67 \\
TL (field study) & 48.22 & 50.77 & 48.23 & 48.57 & 48.87 & 46.73 & 45.92 \\
\hline
\end{tabular}

\section{Modification Design 1}

In the first modification of this design uses wall material with covered corncob which is according to research by Suranto, corncobs have a 0.63 value in the range of $0-1800 \mathrm{~Hz}$. Organic wall panelling in the form of corn cobs with full ratio composition covers the wall surface. As shown in Figure 18.

Tabel 17. TL (dB (A)) Calculating at Frequency of 500-2000 Hz

\begin{tabular}{cccccccc}
\hline Modification 1 & $500 \mathrm{~Hz}$ & $630 \mathrm{~Hz}$ & $800 \mathrm{~Hz}$ & $1000 \mathrm{~Hz}$ & $1250 \mathrm{~Hz}$ & $1600 \mathrm{~Hz}$ & $2000 \mathrm{~Hz}$ \\
TL & 24.78 & 26.80 & 32.99 & 33.56 & 30.38 & 29.80 & 27.17 \\
\hline
\end{tabular}


Tabel 18. LP2 (dB (A)) Calculating of Modification at Frequency $500-2000 \mathrm{~Hz}$

\begin{tabular}{cccccccc}
\hline & $500 \mathrm{~Hz}$ & $630 \mathrm{~Hz}$ & $800 \mathrm{~Hz}$ & $1000 \mathrm{~Hz}$ & $1250 \mathrm{~Hz}$ & $1600 \mathrm{~Hz}$ & $2000 \mathrm{~Hz}$ \\
$\begin{array}{c}\text { LP2 (manual } \\
\text { calculation) }\end{array}$ & 47.97 & 50.52 & 47.98 & 48.32 & 48.62 & 46.48 & 45.67 \\
$\begin{array}{c}\text { LP2 modifica- } \\
\text { tion 1 }\end{array}$ & 35.27 & 38.07 & 38.07 & 38.07 & 38.07 & 38.07 & 38.08 \\
\hline
\end{tabular}

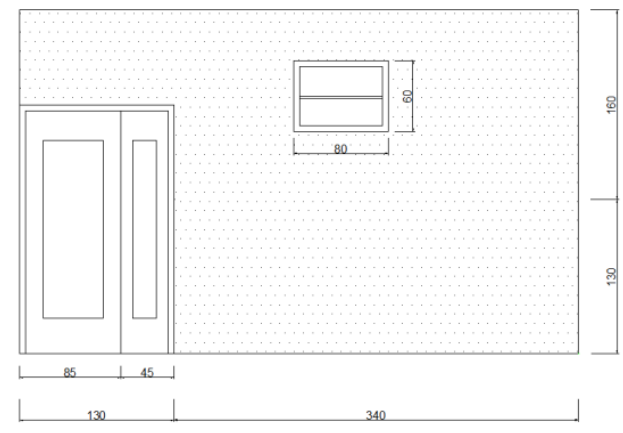

Figure 17. Figure Facing front of Partition with Corncob

From table 17, it can be seen that there is a significant reduction in LP2 of the existing value to the LP2 modification 1 . But only $35 \mathrm{~dB}(\mathrm{~A})$ at a frequency of $500 \mathrm{~Hz}$ reach the standard rate. While the band $630 \mathrm{~Hz}-2000 \mathrm{~Hz}$ is still above of 35 $\mathrm{dB}(\mathrm{A})$.

\section{Modification Design 2}

In the second modification design uses wall materials from coconut coir which according to Kartikaratri's research that coconut coir has a value a 0.9 in the range of 756-6400 Hz. Design partition of organic wall materials in the form of coconut coir panelling with full-ratio composition cover wall surface. As shown in the figure 21.

Table 19. TL (dB (A)) Calculating at Frequency of $500-2000 \mathrm{~Hz}$

\begin{tabular}{cccccccc}
\hline Modification 2 & $500 \mathrm{~Hz}$ & $630 \mathrm{~Hz}$ & $800 \mathrm{~Hz}$ & $1000 \mathrm{~Hz}$ & $1250 \mathrm{~Hz}$ & $1600 \mathrm{~Hz}$ & $2000 \mathrm{~Hz}$ \\
TL sk & 23.00 & 25.02 & 31.21 & 31.77 & 28.39 & 45.21 & 25.38 \\
\hline
\end{tabular}

Table 20. LP2 (dB (A)) Calculating at Frequency of 500-2000 Hz

\begin{tabular}{cccccccc}
\hline & $500 \mathrm{~Hz}$ & $630 \mathrm{~Hz}$ & $800 \mathrm{~Hz}$ & $1000 \mathrm{~Hz}$ & $1250 \mathrm{~Hz}$ & $1600 \mathrm{~Hz}$ & $2000 \mathrm{~Hz}$ \\
LP2 existing & 47.97 & 50.52 & 47.98 & 48.32 & 48.62 & 46.48 & 45.67 \\
$\begin{array}{c}\text { LP2 modifica- } \\
\text { tion 1 }\end{array}$ & 35.27 & 38.07 & 38.07 & 38.07 & 38.07 & 38.07 & 38.08 \\
$\begin{array}{c}\text { LP2 modifica- } \\
\text { tion 2 }\end{array}$ & 35.54 & 35.54 & 35.54 & 35.54 & 35.54 & 35.54 & 35.54 \\
\hline
\end{tabular}




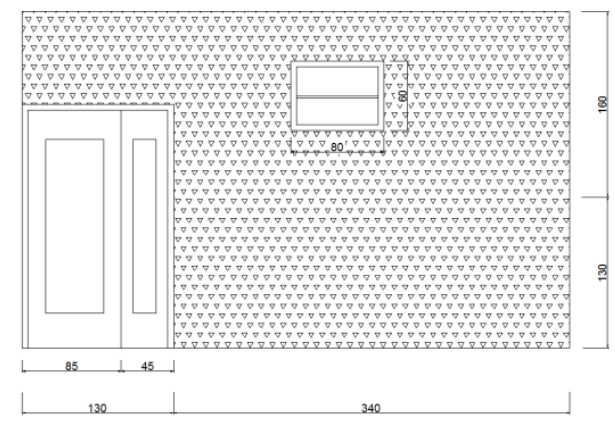

Figure 18. Figure of Wall Partition Using Coconut Coirs

From table 19, it can be seen that there is a significant reduction in LP2 of the existing value to the LP2 modification 2 . With the most of values indicate at 35 $\mathrm{dB}$ (A). It can be concluded that the modification design 2, the wall material from coconut coirs have good absorptive acoustic performance at all the frequencies that need to be reduced in this study.

\section{Modification Design 3}

In the third modification design uses bagasse wall material which according to Anggraini's research in 2010 that coconut coir has a value a 0.8 in the range of 452-2900 Hz. Design partition of organic wall materials in the form of bagasse panelling with full-ratio composition cover wall surface. As shown in Figure 22 below.

Table 21. TL (dB (A)) Calculating at Frequency of 500-2000 Hz

\begin{tabular}{cccccccc}
\hline Modification 3 & $500 \mathrm{~Hz}$ & $630 \mathrm{~Hz}$ & $800 \mathrm{~Hz}$ & $1000 \mathrm{~Hz}$ & $1250 \mathrm{~Hz}$ & $1600 \mathrm{~Hz}$ & $2000 \mathrm{~Hz}$ \\
TLat & 23.83 & 25.85 & 32.04 & 32.61 & 29.23 & 28.85 & 26.62 \\
\hline
\end{tabular}

Table 22. LP2 (dB (A)) calculating at frequency of $500-2000 \mathrm{~Hz}$

\begin{tabular}{cccccccc}
\hline & $500 \mathrm{~Hz}$ & $630 \mathrm{~Hz}$ & $800 \mathrm{~Hz}$ & $1000 \mathrm{~Hz}$ & $1250 \mathrm{~Hz}$ & $1600 \mathrm{~Hz}$ & $2000 \mathrm{~Hz}$ \\
LP2 existing & 47.97 & 50.52 & 47.98 & 48.32 & 48.62 & 46.48 & 45.67 \\
LP2 modifica- & 35.27 & 38.07 & 38.07 & 38.07 & 38.07 & 38.07 & 38.08 \\
$\quad$ tion 1 & & & & & & & \\
$\begin{array}{c}\text { LP2 modifica- } \\
\text { tion 2 }\end{array}$ & 35.54 & 35.54 & 35.54 & 35.54 & 35.54 & 35.54 & 35.54 \\
$\begin{array}{c}\text { LP2 modifica- } \\
\text { tion 3 }\end{array}$ & 35.40 & 35.40 & 35.40 & 35.40 & 35.40 & 35.40 & 35.40 \\
\hline
\end{tabular}

From table 21, it can be seen that there is a significant reduction in LP2 of the existing value to the LP2 modification 2 . With the most of values indicate at 35 $\mathrm{dB}$. It can be concluded that the modification design 3 , the wall material from coconut coirs have good absorptive acoustic performance at all the frequencies that need to be reduced in this study. 


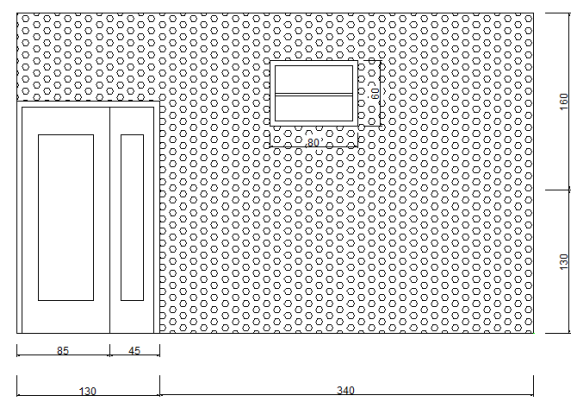

Figure 19. Figure of Partition Using Bagasse Wall Material

\section{Modification Design 4 (Modification 1: Ceramic)}

Design modifications 4 conducts compositions of organic acoustic panelling modification 1 (corncob) with a manufacturer material (ceramic), based on area of an existing area ratio.

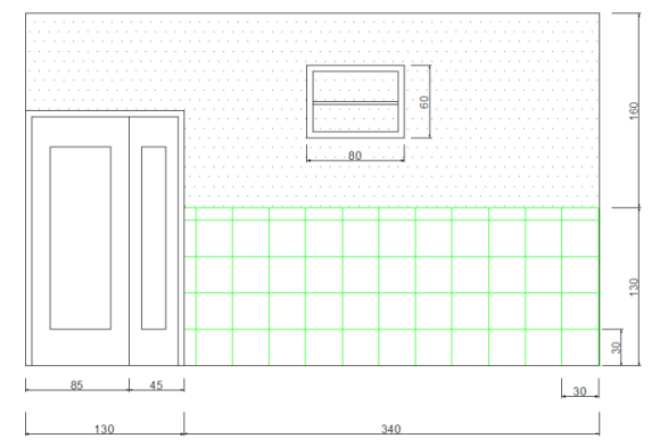

Figure 20. Figure of Partition

Using Bagasse and Ceramic Wall Material

Table 23. TL (dB (A)) Calculating at Frequency of 500-2000 Hz

\begin{tabular}{cccccccc}
\hline $\begin{array}{c}\text { Modification } \\
\text { 1+Ceramic Tile }\end{array}$ & $500 \mathrm{~Hz}$ & $630 \mathrm{~Hz}$ & $800 \mathrm{M}$ & $1000 \mathrm{~Hz}$ & $1250 \mathrm{~Hz}$ & $1600 \mathrm{~Hz}$ & $2000 \mathrm{~Hz}$ \\
TL & 26.92 & 28.90 & 35.09 & 35.67 & 32.29 & 31.91 & 29.29 \\
\hline
\end{tabular}

Table 24. LP2 (dB (A)) Calculating at Frequency of 500-2000 Hz

\begin{tabular}{cccccccc}
\hline & $500 \mathrm{~Hz}$ & $630 \mathrm{~Hz}$ & $800 \mathrm{~Hz}$ & $1000 \mathrm{~Hz}$ & $1250 \mathrm{~Hz}$ & $1600 \mathrm{~Hz}$ & $2000 \mathrm{~Hz}$ \\
LP2 existing & 47.97 & 50.52 & 47.98 & 48.32 & 48.62 & 46.48 & 45.67 \\
$\begin{array}{c}\text { LP2 modifica- } \\
\text { tion 1 }\end{array}$ & 35.27 & 38.07 & 38.07 & 38.07 & 38.07 & 38.07 & 38.08 \\
$\begin{array}{c}\text { LP2 modifica- } \\
\text { tion 2 }\end{array}$ & 35.54 & 35.54 & 35.54 & 35.54 & 35.54 & 35.54 & 35.54 \\
\hline
\end{tabular}


Table 24. Continue

\begin{tabular}{cccccccc}
\hline & $500 \mathrm{~Hz}$ & $630 \mathrm{~Hz}$ & $800 \mathrm{~Hz}$ & $1000 \mathrm{~Hz}$ & $1250 \mathrm{~Hz}$ & $1600 \mathrm{~Hz}$ & $2000 \mathrm{~Hz}$ \\
$\begin{array}{c}\text { LP2 modifica- } \\
\text { tion 3 }\end{array}$ & 35.40 & 35.40 & 35.40 & 35.40 & 35.40 & 35.40 & 35.40 \\
$\begin{array}{c}\text { LP2 modifica- } \\
\text { tion 4 }\end{array}$ & 35.06 & 35.03 & 35.06 & 35.03 & 35.06 & 34.63 & 35.06 \\
\hline
\end{tabular}

From table 23, it can be seen that the comparison between full partitions of organic material (corncob) are modifications 1 and 4 (ceramics combination), there is a significant difference from the frequency of $630 \mathrm{~Hz}$. It can be concluded that the damping performance of modification design 4 (combination of corncob and ceramics) is better and stable in any frequency band than modifaction 1 which uses a full layer of corncob.

\section{Modification Design 5 (Modification 4 : Ceramic)}

Modification design 5 is similar with 4 that conducts a composition of organic acoustic panel but using modification 2 (coconut coir) with a manufacturer material (ceramic). Based on the area of existing ratio. As shown in the figure below.

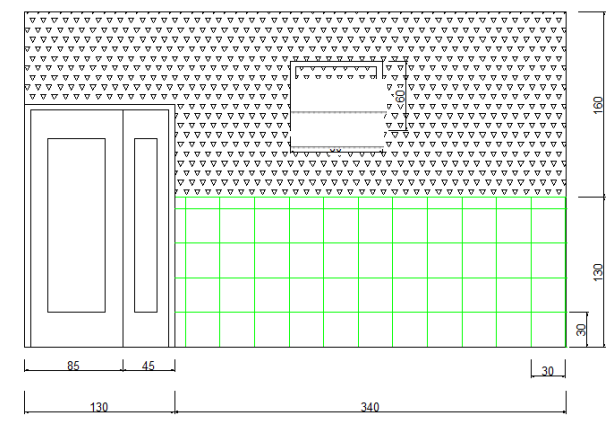

Figure 21. Figure of Partition Using Coconut Coirs and Ceramic Wall Material

Table 25. TL (dB (A)) Calculating at Frequency of 500-2000 Hz

\begin{tabular}{cccccccc}
\hline $\begin{array}{c}\text { Modification } \\
\text { 2+Ceramic Tile } \\
\text { TL }\end{array}$ & $500 \mathrm{~Hz}$ & $630 \mathrm{~Hz}$ & $800 \mathrm{~Hz}$ & $1000 \mathrm{~Hz}$ & $1250 \mathrm{~Hz}$ & $1600 \mathrm{~Hz}$ & $2000 \mathrm{~Hz}$ \\
\hline
\end{tabular}

Tabel 26. LP2 (dB (A)) Calculating at Frequency of 500-2000 Hz

\begin{tabular}{cccccccc}
\hline & $500 \mathrm{~Hz}$ & $630 \mathrm{~Hz}$ & $800 \mathrm{~Hz}$ & $1000 \mathrm{~Hz}$ & $1250 \mathrm{~Hz}$ & $1600 \mathrm{~Hz}$ & $2000 \mathrm{~Hz}$ \\
LP2 existing & 47.97 & 50.52 & 47.98 & 48.32 & 48.62 & 46.48 & 45.67 \\
LP2 modifica- & 35.27 & 38.07 & 38.07 & 38.07 & 38.07 & 38.07 & 38.08 \\
$\quad$ tion 1 & & & & & & & \\
$\begin{array}{c}\text { LP2 modifica- } \\
\text { tion 2 }\end{array}$ & 35.54 & 35.54 & 35.54 & 35.54 & 35.54 & 35.54 & 35.54 \\
\hline
\end{tabular}


Table 26. Continue

\begin{tabular}{cccccccc}
\hline & $500 \mathrm{~Hz}$ & $630 \mathrm{~Hz}$ & $800 \mathrm{~Hz}$ & $1000 \mathrm{~Hz}$ & $1250 \mathrm{~Hz}$ & $1600 \mathrm{~Hz}$ & $2000 \mathrm{~Hz}$ \\
$\begin{array}{c}\text { LP2 modifica- } \\
\text { tion 3 }\end{array}$ & 35.40 & 35.40 & 35.40 & 35.40 & 35.40 & 35.40 & 35.40 \\
$\begin{array}{c}\text { LP2 modifica- } \\
\quad 35.06\end{array}$ & 35.03 & 35.06 & 35.03 & 35.06 & 34.63 & 35.06 \\
$\begin{array}{c}\text { tion 4 } \\
\begin{array}{c}\text { LP2 modifica- } \\
\text { tion 5 }\end{array}\end{array}$ & 35.22 & 35.21 & 35.22 & 35.20 & 35.22 & 34.94 & 35.22 \\
\hline
\end{tabular}

From table 25, it can be seen the value comparison of LP2 between the full partition of organic material (coconut coirs), modification 2 and 5 (ceramic combination). There is no significant differences, relatively stable at frequency of $500 \mathrm{~Hz}$ to $1250 \mathrm{~Hz}$.

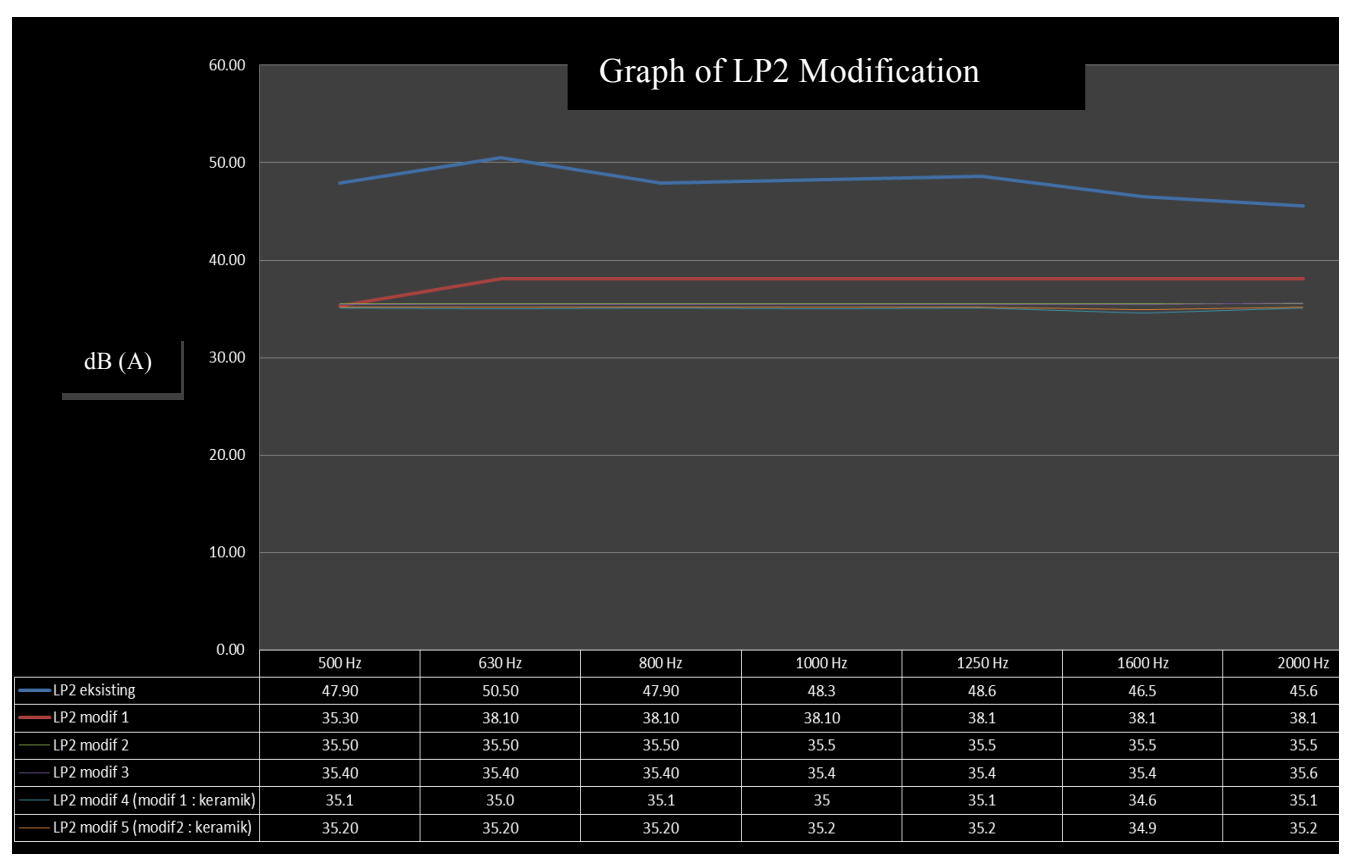

Figure 22. Figure of LP2 Modification Graph of the Research Subject (Habitable Room)

From the graph above, it can be seen that all three organic materials (corncob, bagasse and coconut coir) which have been able to achieve the standard rate, because they can reduce noise up to the value of around $35 \mathrm{~dB}$ LP2. Either designed with full organic or combined with ceramics.

However, from the three organic materials that are applied to whole partitions (modification 1, 2 and 3) which has the best value is modification 3, wall with bagasse. While the partition design with organic material and ceramic combination which have the best acoustic performance is modification 4 , the wall with corncobs and ceramic combination. Modification 4 is the best design solution 
amongst all experimental designa alternatives above, is the wall with corncobs and combination of ceramic.

\section{CONCLUSIONS}

From 5 design treatments for partition walls of the research subject showed that to apply the three types of organic materials are able to achieve an acoustic comfort in a habitable room, because it can reduce noise up to the value of LP2 around $35 \mathrm{~dB}$ (A). However, the modification 4 (modification corncob + ceramics) has the most excellent damping performance, because it has the lowest LP and stable at all frequencies. Followed by modification 5 where they both use a combination of ceramic. It concluded that a combination between organic and anorganic material are the proper selection for the design of a partition wall in habitable room of motorcycle repair home business.

\section{REFERENCES}

Barron, M. (2001), Late Lateral Energy Fractions and the Envelopment Question in Concert Halls, Applied Acoustics.

Doelle, L. L. and Prasetio L. (1972), Akustik Lingkungan. Erlangga, Jakarta.

Groat, L. and Wang, D. (2002), Architectural Research Methods, John Willey and Sons, Canada.

Hemond, C. J. (1983), Engineering Acoustics and Noise Control, Prentice-Hall. the University of Michigan.

Long, M. (2006), Architectural Acoustics, Elseiver: Academic Press, America.

Mediastika, C. E. (2005), Akustika Bangunan. Erlangga, Jakarta.

Mediastika, C. E. (2009), Material Akustik Pengendali Kualitas Bunyi pada Bangunan, Andi Offset, Yogyakarta.

Silas, J. (1993), Housing Beyond Home: The Aspect of Resources and Sustainability, Pidato Pengukuhan Guru Besar, Institut Teknologi Sepuluh Nopember, Surabaya.

Silas, J. (2000), Rumah Produktif, Laboratorium Perumahan dan Permukiman, ITS, Surabaya

Direktorat Jenderal Bina Marga, Standar Perencanaan Geometrik Jalan Perkotaan (1988)

PP no.43/1993

UU no.13/1980 dan PP no.26/1985

www.smart.surabaya.go.id 
Austin, Defiana, Arifianto: THE EFFECT OF ROOM MATERIAL TO OVERCOME THE NOISE DUE TO MOTORCYCLE WORKSHOP ACTIVITY AT HOME BASED-ENTERPRISED NEARBY ROADWAY

This page is intentionally blank 